\title{
Lamina Spiralis Ossea
}

National Cancer Institute

\section{Source}

National Cancer Institute. Lamina Spiralis Ossea. NCI Thesaurus. Code C32921.

The bony projection from the inner wall of the modiolus that makes two and three

quarter turns around the modiolus partially dividing the cochlea cavity. 